\title{
The effect of talent management and emotional intelligence on organizational performance: Applied study on pharmaceutical industry in Jordan
}

\author{
Marzouq Ayed Al-Qeed \\ The World Islamic Science \& Education University, Amman, Jordan \\ Amineh Abdul Halim Khaddam \\ Amman Arab University, Jordan \\ Zeyad Faisal Al-Azzam \\ Education Malaysia Jordan, Embassy of Malaysia, Jordan \\ Khalid Abd El Fattah Atieh \\ Arab American University, Palestine
}

Keywords

Talent Management; Emotional Intelligence; Performance; Pharmaceutical Industry; Jordan

\begin{abstract}
This paper studies the impact of talent management on organizational performance in Jordanian pharmaceutical companies and evaluates the mediating role of emotional intelligence in the relationship between talent management and organizational performance. A survey was distributed among managers of pharmaceutical companies in Jordan, and 1125 responses were collected. The respondent sample was constructed using random stratified sampling. The PLS-SEM was used to test the hypothesized relationships of the model. The study result revealed positive relationships between (1) talent management and organizational performance, (2) talent management and emotional intelligence, and (3) emotional intelligence and organizational performance. Employing PLS path modelling to evaluate the structural model is highly original. The paper emphasizes the importance of emotional intelligence as a mediator of the relationship between talent management and organizational performance in the pharmaceutical industry of Jordan.
\end{abstract}

Corresponding author: Marzouq Ayed Al-Qeed

Email addresses for corresponding author:dr_marzouq@yahoo.com

First submission received: $3^{\text {rd }}$ January 2018

Revised submission received: $11^{\text {th }}$ February 2018

Accepted: $5^{\text {th }}$ March 2018

\section{Introduction}

Successive technological developments and global economic systems forced organizations to diversify their resources to accommodate and adapt to new challenges in which public and private organizations create their survival and growth strategies in a hyper competitive environment. Human resources now have a vital role in helping organizations compete and achieve their goals; effective and efficient employees are considered a competitive advantage. Firms that want to survive, grow, and sustain their competitive advantage will work to attract, hire, cultivate, develop, and retain employees, especially those with extraordinary talents, to create value (Horváthová, 2011). Two points of view about talent arose: the first is that talented individuals expend extraordinary efforts and have potential that affect organizations effectiveness; the second view is that all employees represent talent through their contributions to achieve the organization's objectives (Kehinde, 2012). In other words, a talented employee has the highest performance and high potential to do so.

However, authors see talent as belonging to individuals possessing a triangle of knowledge, skills, and capabilities, along with showing high potential to perform efficiently and effectively. This study hypothesizes that the main task of human resource departments in today's organizations is to search for, discover, develop, and preserve talent. Noteworthy, talent and talent management strategies cannot 
achieve the desired results without integrating employee engagement in organizations' strategies (Payambarpour \& Hooi, 2015; Hanif \& Yunfei, 2013).

Recent studies show that organizations will face major challenges now and in the future related to talented employees, which might affect their organizational growth and development. Clearly, the foundation of every organization's potential for future success ultimately depends on the strength of its talent. Thus, effective talent management has become so crucial to business growth and economic progress that it is forcing organizations to re-examine how they attract, develop, retain, and engage employees (Tajuddin, Hassan, Syed, \& Ali, 2016).

In the context of Arab business organizations, similar to other public and private organization of the world, Jordanian public and private organizations suffer from both shortages of skilful and talented employees and low performance. These organizations are facing migrating and depleting talents because they are in high demand. However, public and private organizations in Jordan have not realized the importance of dealing with their talents or discovering hidden ones. Other studies conducted in the Arab context have obviously proved that many Arab and Jordanian organizations solely attract talents expecting to perform higher and achieve much more without giving special attention to who are those talents. Lately, the pharmaceutical industry in Jordan has started suffering from talent migration or depletion. Hence, talented individuals who are distinguished by their abilities, skills, knowledge and distinctive competencies are being attracted by other global competitors. Therefore, this study aims to examine the effect of talent management on organizational performance at pharmaceutical industry in Jordan.

\section{Literature review and research model}

2.1. Talent management and organizational performance

In today's knowledge economy, talents are becoming not only important but also scarce. Scholars believed that talent was always inherited and predetermined by genes. Others believed that when a person is born, he will have an innate readiness for being talented. According to Clake and Winkler (2006) and Elegbe (2010), talents can be developed through the environment that would shape his/her behaviour; otherwise, he will remain invisible. This talent can be divided into the following types; general talent is expressed by general intelligence, where intelligence is the main measure of talent, and special ability, which may be in the specific field, and a person with it performs a certain work with a high degree of creativity and innovation. Thus, talent is intelligence with effort. Jyoti and Rani (2014) define talent as high performers and high potential employees, who have a sharp strategic mindset, managerial, communication, and functional skills, experience, commitment and contribution behaviour that results in outstanding performance. The term "War of Talent" was launched in 1998 by McKinsey \& Company and proclaimed that "the better talent is worth fighting for". Thus, McKinsey defines talent as "the sum of a person's abilities- his or her intrinsic gifts, skills, knowledge, experience, intelligence, judgement, attitude, character and drive, it also includes his or her ability to learn and grow" (Michaels, Jones, \& Axelrod, 2001: xii; Schiemann, 2014). Moreover, talent can be defined as the person who consistently shows outstanding performance in any field with cognitive or valuable abilities (Cooke, Saini, \& Wang, 2014). Daveis and Daveis (2010) have a different perspective of talent management. They considered it as systematic and ongoing processes that include certain processes such identifying, developing and retaining talents.

Indeed, certain factors might be impacting the war for talent, such as global demographics, economic trends, increasing mobility, diversity, and transformational changes. Different factors affecting talent management are explicitly listed, such as corporate culture, work environment, top management commitment, financial allocations to talent management and communications (Abdul-Kareem, 2016). To address the gap of knowing-doing in talent management that is imposed on organizations, they should eliminate traditional business models and scarcity mindsets and adopt new approaches to finding, nurturing, stimulating, motivating, and retaining global talents (Haines, 2013). These are innovative, integrated and strategic responses, rather than tactical battles, to create more cooperative and generative talent approaches (Beechler \& Woodward, 2009). However, too many studies have focused on the expected results of investigating talent management, such as motivation, competitive advantage, human resource practices and commitment (Vaiman, Scullion \& Collings, 2012; Stahl et al., 2012; Cappelli \& 
Keller, 2014). However, the definition of talent is still debatable between scholars and authors (Thunnissen, Boselie \& Fruytie, 2013; Gallardo-Gallardo, Dries \& Gonzalez-Cruz, 2012; Tansley, 2011; Lewis \& Heckman, 2006).

Therefore, in the early 1990s, the term talent management emerged and was popularized by many researchers and practitioners as hyper competition dominated. According to researchers and practitioners, the term is still young and evolving (Collings, Scullion \& Vaiman, 2011), as well as contributing to bridging the gap between talent demand and talent supply by considering the flow of talent through an organization that will certainly align individual goals to organizational goals and workforce strategies to business strategies (Jyoti \& Rani, 2014; Hilal, 2012; Iles, 2008). Moreover, others defined talent management as organizational procedures related to analysing, identifying, selecting, training, developing, motivating, and retaining the higher performers and high potential employees to ultimately achieve organizational strategic goals (Valverde, Scullion \& Ryan, 2013; Nankervis, 2013; Bano, Khan, Rehman \& Humayoun, 2010; Silzer \& Church, 2010).

In other perspectives, some authors viewed talent management as a new technique in human resource management focused on recruitment, retention, developing leadership competencies, career path, succession planning, and more (Kaur, 2013; Piansoongnern, Anurit \& Kuiyawattananonta, 2011; Thunnissen, et al., 2013; Collings \& Mellahi, 2009; Vaiman, Haslberger \& Vance, 2015; Gallardo-Gallardo, Nijs, Dries \& Gallo, 2015). Meanwhile, others urge that talent management is future-oriented and fulfils strategic goals (Vaiman \& Collings, 2013; Lewis \& Heckman, 2006; Schweyer, 2004; Anwar, Nisar, Khan \& Sana, 2014). Therefore, organizations started to seek and nurture those talents inside and outside its boundaries. Based on the foremost contributions, the authors can define talent management as a set of organizational activities to attract, hire, train, develop, motivate and retain talents to meet the current and future organizations' objectives and seek a sustainable futuristic leadership (Sart, 2014).

Generally, most scholars and practitioners symmetrically agree on the following four components of talent management strategies that organizations should implement: talent attraction, talent development, talent retention and succession planning (Irtaimeh, Al-Azzam \& Khaddam, 2016). In fact, too many models based on talent management are still considering talents as the ability of a person to perform high, which increases success and leads to better results (Ross, 2013; Latukha \& Selivanovskikh, 2016; Latukha, 2016). Numerous studies have been conducted to determine the relationship between human resources or talent management and organizational performance in different contextual environments. Thus, they have proclaimed that a positive relationship exists either between human resource practices or talent management and organizational performance (Arif \& Uddin, 2016; Maya \& Thamilselvan, 2013; Ibidunni, Osibanjo, Adeniji, Salau \& Falola, 2016; Davies \& Davies, 2010; Ingram, 2016; Al-Azzam, Irtaimeh \& Khaddam, 2017). Hence, we hypothesize that

Hypothesis 1: There is a positive relationship between talent management and organizational performance.

\subsection{Talent management and emotional intelligence}

Interrelationships have attracted much attention where emotional intelligence plays a critical role in aligning employees with their can-do-attitude. Furthermore, they will be engaged and perform highly to achieve organizational strategic goals set out by their leaders. Employees will feel valued, trusted, respected and appreciated if they are properly emotionally treated. Darwin's contributions gave more insights into emotion intelligence. Anecdotal studies have proved that leaders are more intelligent than others in the organization since they are a critical factor of success. Emotional intelligence originated in the 1920s when Thorndike first proposed classifying EI into abstract intelligence, mechanical intelligence and social intelligence (Asrar-ul-Haq, Anwar \& Hassan, 2017). Gardner (1983) suggested the following two new classification of EI: intra-emotions and inter-emotions (Calik \& Birgili, 2013; Gardner \& Hatch, 1989). Several scholars made extra contributions regarding EI. Emotional intelligence theory was developed by Mayor and Salovey in 1990. They defined it as the ability to understand one's and others' emotions and to build an emotionally based relationship with others to emotionally adapt to the changing environment, changing circumstances and changing needs (Mayer \& Salovey, 1990 \& 1997). Subsequently, Goleman built his contributions based on Mayor's and Salovey's theory of EI. He defined EI as the one's ability to utilize his/her skills to catch up their state of consciousness, improve self-management, and understand 
their own and others' feelings (empathy) by running strong relationships (Shayanipour, Imani \& Karimzadeh, 2017; Srivastava, 2013). Another definition of EI refers to the ability to recognize, manipulate and influence one's and others' emotions (Keating, Harper \& Glew, 2013).

According to Mayor and Salovey (1997), emotional intelligence is divided into the following four areas; Perceiving emotions means recognizing the nonverbal or expression emotions of others that appear through any means of contact. Using emotions to facilitate thoughts assists individual thinking regarding developing knowledge-based experiences to guide ones' behaviour. Understanding emotions after recognizing ones' emotions, analysing these emotions and anticipating the results of these emotions is the main idea of understanding how emotions works. Finally, managing emotions reflects the ability of individuals to use their personality traits to handle these emotions based on their own knowledge and social awareness (Mayor, Salovey \& Caruso, 2004). Symmetrically, Wong \& Law (2004) propounded that EI consists of the following four dimensions: self-emotional appraisal, others-emotional appraisal, the regulation of emotions, and the use of emotions. Additionally, Goleman and Boyatzis (2008) classified EI into the following four clusters: self-awareness, self-management, social awareness and relationship management (Al-Azzam, 2015).

Therefore, the current factors encourage organizations to adapt and implement talent management strategies to confront strategic surprises in a massive turbulent environment. However, neither attracting nor retaining talent will be useful without considering talent development. Talent development includes learning and building strong knowledge to effectively solve organizational problems in conjunction with dealing with others. Notwithstanding, talent development means engaging employees with all related strategic planning and goals of organization, so they can feel part of the solution. Palmer \& Gignac (2012) found that emotionally intelligent leadership was correlated with employee engagement. Moreover, Hakkak, Nazarpoori, Mousavi \& Ghodsi. (2015) found that emotional intelligence has a positive effect on social-mental factors of human resources. Further studies show that emotional intelligence has a great impact on organizations and motivating human activity (Agnello, Ryan \& Yusko, 2015; Brouwers \& Vijver, 2015; Schneider \& Newman, 2015; Fagan \& Ployhart, 2015; Scherbaum \& Goldstein, 2015). It means that EI is highly significant in the development of human potential, teamwork, effective leadership, stress reduction, creativity and innovation (Chopra \& Kanji, 2010). Thus, emotionally intelligent employees exhibit better skills (Antonakis, Ashkanasy \& Dasborough, 2009; Njoroge \& Yazdanifard, 2014). They will be able to enhance employees' efficiency and performance in a group through increasing their cooperation and reducing conflicts, especially when their positive emotions are developed between employees in a group (Mayer, Roberts \& Barsade, 2008). Al Jarrah and Abu-Doleh (2015) investigated applying talent management strategies to organizational affiliations at Jordanian universities. They revealed a significant and extrusive correlation with the application of talent management strategies at the level of organizational affiliation. Therefore, we hypothesize that:

Hypothesis 2: There is a positive relationship between talent management and emotional intelligence.

\subsection{Emotional Intelligence and Organizational Performance}

The development of emotional intelligence has occurred since the first models were developed by Slaovey and later Goleman. The models proposed that individuals with higher intelligence quotient (IQ) have better abilities to listen, learn and understand than those with lower scores. This finding indicates that people with higher levels of emotional intelligence have better job performance, strong personal relationships, more effective leadership skills and are healthier than those with low emotional intelligence (Cooper, 1997). Since then, many studies have been conducted to examine the reciprocal relationship between emotional intelligence and business organizations' performance. Lyons and Schneider (2005) examined the relationship of ability-based EI facets with performance under stress. Their study revealed that high levels of EI would promote challenge appraisals and better performance, whereas low EI levels would foster threat appraisals and worse performance. Certain dimensions of EI were related to more challenges and enhanced performance. Some EI dimensions were related to performance after controlling for cognitive ability and demonstrating incremental validity. This pattern of findings differed somewhat for males and females. O'Boyle, Humphrey, Pollack, Hawver \& Story (2011) conducted a meta-analysis study that examined the relationship between emotional intelligence and job performance and put 
emotional intelligence into the following three streams of emotional competencies: ability-based, selfreported (peer-reported) and mixed models. They concluded that all three streams are differently correlated with cognitive abilities and with neuroticism, extraversion, openness, agreeableness, and conscientiousness that are differently associated with job performance. Moreover, Mohamad and Jais (2016) found that emotional intelligence and its four dimensions (self-awareness, self-regulation, selfmotivation, empathy, and social skills) have a greater impact on teachers' job performance.

Likewise, recent studies uncovered a strong linkage between emotional intelligence and job \& organizational performance (Pekaar, Linden, Bakker \& Born, 2017; Abraham, 2004; Jorfi, Jorfi \& Moghadam, 2010; Higgs, 2004; Codier, Kamikawa, Kooker \& Shoultz, 2009; Gutiérrez-Cobo, Cabello \& Fernández-Berrocal, 2017; Gutiérrez-Cobo, Cabello \& Fernández-Berrocal, 2017; Arribas-Galarraga, Saies, Cecchini, Arruza \& Cos, 2017; Chaudhry \& Usman, 2011). Emotional intelligence equips individuals with the skills to anticipate their performance, especially in teamwork (Offermann, Bailey, Vasilopoulos, Seal \& Sass, 2004). Daneshfard, Rajaei, Bilondi \& Banihashemi (2016) examined the effect of organizational intelligence and talent management. They defined organizational intelligence as a combination of human intelligence and machine intelligence and discovered the effect of each component. Their study revealed that organizational intelligence has a direct and positive effect on talent management which, in turn, impacted the productivity of organizations' human resources. Others have conducted studies in the field of nursing and uncovered that there is no significant relationship between emotional intelligence and nurses' perceived job performance (Vahidi, Areshtanab \& Bostanabad, 2016; Talarico, Metro, Patel, Carney \& Wetmore, 2008; Healy, El-Atroush, Abol-Enein \& El-Sayed, 2013; Golparvar \& Khaksar, 2010). This finding was obscure and suspicious to the current researcher. Thus, the researcher proposes the following hypothesis:

\section{Hypothesis 3: There is a positive relationship between emotional intelligence and organizational performance.}

Despite the agreement between most studies regarding the relationships between talent management and organizational performance, talent management and emotional intelligence and emotional intelligence and organizational performance, none of these studies have examined the role of emotional intelligence as a mediator in the relationship between talent management and organizational performance. Based on the literature review, emotional intelligence is expected to reinforce talent management competencies, which in turn is likely to affect (positively or negatively) organizational performance. The direction of this effect $( \pm)$ can be identified using empirical analysis where our argument is going to be empirically tested. Typically, in this regard, the current research will examine the effect of emotional intelligence in the relationship between talent management and organizational performance as is depicted in the research model (Figure 1). Therefore, the researcher hypothesizes the following.

\section{Hypothesis 4: Emotional intelligence mediates the relationship between talent management and organizational performance.}

\section{Conceptual framework}

In the contemporary business environment, globalization and competitiveness are overall predominant. These integration trends imposed on all organizations to develop its own standards so as apparently to acquire better competitive level. Thus, turning toward talent management is becoming the valuable strategic choice that eventually boosts the organization's performance and that is why talent management is gaining popularity nowadays. Talent management is a process which consists of four strategies namely; talent attraction, talent development, talent retention and talent succession, which is used to boost organizational performance through a dynamic interrelationship between them. However, intelligent organizations have employed emotional intelligence as a methodology to come close with its employees to motivate them to enhance their productivity and performance. Therefore, most of the studies suggested that talent management can influence both individual and organizational performance.

Several studies have identified emotional intelligence as EI or EQ, which fall into two categories that each have two sub-categories: personal competence; consists of self-awareness and self-management, and social competence; consists of social awareness and relationship management. The latter, relationship 
management, is tied to the ones' ability to read other emotions by using own awareness to build relationships, communicate, and navigate interactions with others successfully. The major conceptual models of emotional intelligence are divided into three models; (1) the Salovey-Mayer model; (2) the Goleman model; and (3) the Bar-On model. Even though other study proved the effect of emotional intelligence on organizational performance (Rahim \& Malik, 2010), it still energizes behaviour needed and implies rational thinking, especially during the tough situations. Therefore, this study comes to investigate the role of emotional intelligence as a mediator in the relationship between talent management and organizational performance (figure 1 illustrates the study conceptual framework) where the employees' emotional intelligence is the core investigation of this study contrary to previous studies which were carried on the leadership emotional intelligence in business organizations.

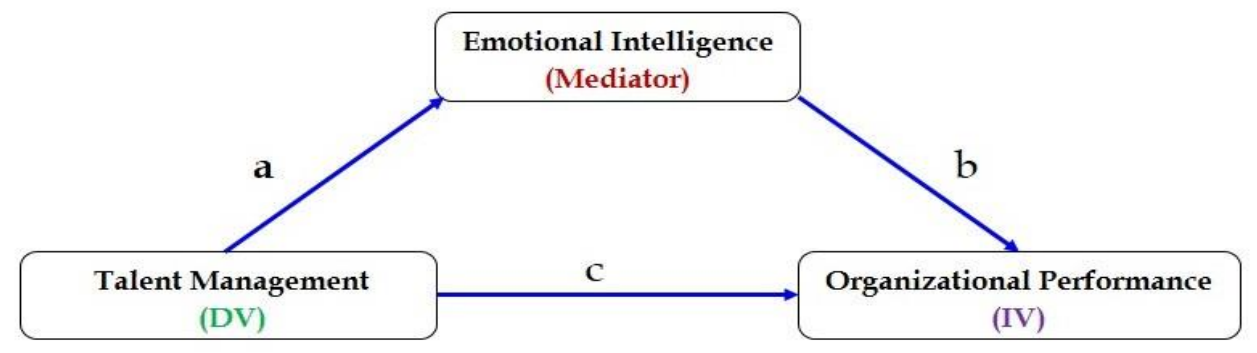

\section{Methodology}

Figure 1: Research model: TM - EI - OP relationship (developed by authors)

Generally, previous studies have proven the positive and significant relationships of talent management with organizational performance, talent management with emotional intelligence and emotional intelligence with organizational performance (Shemi, Mohsen \& Mahboobeh, 2013; Mensah, 2015). Therefore, the main objective of the current research is to examine the effect of emotional intelligence (EI) as a mediator on the relationship between talent management (TM) and organizational performance (OP) in the Jordanian pharmaceutical industry, which has never been studied. Therefore, a quantitative methodology has been employed between the research variables.

\subsection{Population and Sampling}

The population of the current research consists of 15 pharmaceutical companies working in the Jordanian market. The sample was chosen using random stratification of the 15 of pharmaceutical companies operating in Jordan. A total of 1125 questionnaires were distributed to employees working in these pharmaceutical companies, and only 985 questionnaires were returned. Reviewing these questionnaires uncovered that only 969 questionnaires were valid for statistical analysis, resulting in an effective response rate of $86.1 \%$.

\subsection{Measurement}

Based on the aforementioned literature review, a structured in-depth questionnaire was administered to collect the data. A survey instrument adopted from Irtaimeh et al. (2016) \& Al-Azzam et al. (2017) was developed to separately uncover the talent management dimensions such as attraction, development, retention and succession planning; the emotional intelligence dimensions such as selfawareness, self-management, the social relationship and awareness management adopted from Goleman (1995); and the organizational performance dimensions. These items were measured by respondents using a Five Point-Likert type scale that ranged from 1, strongly agree, to 5, strongly disagree.

\subsection{Validity and Reliability}

This instrument has undergone face validity through academicians and experts in the field of talent management and emotional intelligence to check whether the instrument was properly constructed to measure the variables. The inter-correlations of the questionnaire items can provide a measure of internal consistency (reliability). Therefore, the researcher conducted a standard internal consistency check of questionnaire items using Cronbach's Alpha, where its values range from $0-1.0$. Consequently, the coefficient value should be at least 0.70 or higher, although a value from 0.60 to 0.70 is considered 
acceptable (Hair, Black, Babin, Anderson \& Tatham, 2010). Table 1 illustrates the results of this test with the means and standard deviations.

Table 1. Cronbach's alpha of research variables

\begin{tabular}{cccc}
\hline \multicolumn{1}{c}{ Variables } & Means & Standard Deviation & Cronbach's Alpha \\
\hline Talent Management Strategies & 4.13 & 0.701 & 0.942 \\
Talent Attraction & 3.97 & 0.675 & 0.846 \\
Talent Development & 4.01 & 0.732 & 0.881 \\
Talent Retention & 3.78 & 0.770 & 0.918 \\
Succession Planning & 3.86 & 0.794 & 0.879 \\
\hline Emotional Intelligence & 3.98 & 0.837 & 0.895 \\
Self-Awareness & 3.73 & 0.728 & 0.734 \\
Self-Management & 3.67 & 0.689 & 0.896 \\
Social Awareness & 3.65 & 0.871 & 0.799 \\
Relationship Management & 4.15 & 0.703 & 0.801 \\
\hline Organizational Performance & 4.52 & 0.822 & 0.913 \\
Operational Performance & 3.89 & 0.698 & 0.788 \\
Financial Performance & 4.10 & 0.823 & 0.897 \\
Technical Performance & 3.93 & 0.765 & 0.945 \\
\hline
\end{tabular}

\section{Results}

In this section, the researcher adopted the approach proposed by Baron and Kenny (1986) that includes four steps to test the mediational hypothesis and show the causal chain. Several regression analyses should be conducted, and the significance of the coefficients should be examined at each step. In the first simple regression analysis step, the independent variable should predict the dependent variable. In the second simple regression analysis step, the independent variable should predict the mediator. In the third simple regression analysis, the mediator should predict the dependent variable. In the last step, a multiple regression analysis should be conducted with the independent variable and the mediator predicting dependent variable. However, two problems may arise. First, if the effect of the independent variable is no longer significant while controlling for the mediator, the findings will support the full mediation. If the effect of the independent variable is decreased but still significant, then the findings support a partial mediation.

In the first step, a simple regression analysis conducted, and the independent variable talent management was significantly correlated with dependent variable organizational performance $(\beta=0.623, p<$ $0.001)$. Hence, this finding supports the first hypothesis $\left(\mathrm{H}_{0} 1\right)$ that "there is a positive relationship between talent management and organizational performance". Therefore, the null hypothesis is rejected. Table 2 shows the result of regression analysis for the mediation of the effect of talent management on organizational performance through emotional intelligence.

Table 2. Regression analysis for mediation of the effect of talent management on organizational performance through emotional intelligence

\begin{tabular}{|c|c|c|c|c|}
\hline Variables & $\begin{array}{c}\text { Step } 1 \\
\text { Organizational } \\
\text { Performance }\end{array}$ & $\begin{array}{c}\text { Step } 2 \\
\text { Emotional } \\
\text { Intelligence }\end{array}$ & $\begin{array}{c}\text { Step } 3 \\
\text { Organizational } \\
\text { Performance }\end{array}$ & $\begin{array}{c}\text { Step } 4 \\
\text { Organizational } \\
\text { Performance }\end{array}$ \\
\hline Constant & $4.284^{* * *}$ & $3.593^{* * *}$ & $4.072^{* * *}$ & $4.638^{* *}$ \\
\hline Talent Management & $0.623^{* * *}$ & $0.497^{* * *}$ & & $0.581^{* * *}$ \\
\hline Emotional Intelligence & & & $0.504^{* * *}$ & $0.310^{* * *}$ \\
\hline $\mathrm{R}$ & 0.623 & 0.497 & 0.504 & 0.611 \\
\hline $\mathrm{R}^{2}$ & 0.388 & 0.247 & 0.254 & 0.373 \\
\hline Adj. $\mathrm{R}^{2}$ & 0.384 & 0.241 & 0.250 & 0.368 \\
\hline F-value & $110.183^{* * *}$ & $92.469 * * *$ & $97.739 * * *$ & $90.223 * * *$ \\
\hline
\end{tabular}


In the second step, a simple regression analysis was conducted that assessed model 2 . The independent variable talent management was significantly correlated with the mediator emotional intelligence $(\beta=0.497, p<0.001)$. Thus, the results support the second hypothesis $\left(\mathrm{H}_{0} 2\right)$ that "there is a positive relationship between talent management and emotional intelligence". In the third step, the mediator emotional intelligence was significantly correlated with the dependent variable organizational performance $(\beta=0.504, p<0.001)$. By this finding, the researcher strongly rejects the null hypothesis and accepts the third hypothesis $\left(\mathrm{H}_{0} 3\right)$ that "there is a positive relationship between emotional intelligence and organizational performance". In the fourth step, according to Baron and Kenny (1986), a multiple regression analysis was conducted where both the independent variable talent management and the mediator emotional intelligence were regressed together to predict the dependent variable organizational performance. The results in table 2 show that the direct effect of talent management on organizational performance of the first regression model $(\beta=0.623, p<0.001)$ was reduced in the fourth regression model, but it was still significant $(\beta=0.581, p<0.001)$. This conveys that partial mediation may exist.

The potential problem with the approach used is that it never tests the significance of the indirect effect. Therefore, an alternative, and the strongest, approach is to calculate the indirect effect and its significance. Thus, to calculate the indirect effect and its significance, the researcher implemented the suggested method of Sobel (1982) that considers multiplying the two regression coefficients of step 3 and step 2. It can be summarized as follows:

$$
\begin{aligned}
& B_{\text {indirect }}=(\text { Regression coefficient of step } 3)(\text { Regression coefficient of step } 2) \\
& B_{\text {indirect }}=(0.504)(0.497) \\
& B_{\text {indirect }}=\mathbf{0 . 2 5 1}
\end{aligned}
$$

To ensure the significance of the indirect effect of talent management on organizational performance through emotional intelligence, the Sobel test is recommended. The Sobel test equation consists of the following (MacKinnon \& Dwyer, 1993; MacKinnon, Warsi, \& Dwyer, 1995):

$$
\text { Z-value }=a^{*} b / S Q R T\left(b^{2 *} s_{a}{ }^{2}+a^{2 *} s^{2}\right)
$$

Preacher \& Hayes (2008) developed an interactive calculation tool for the mediation test (Sobel test), as shown in figure 2 .

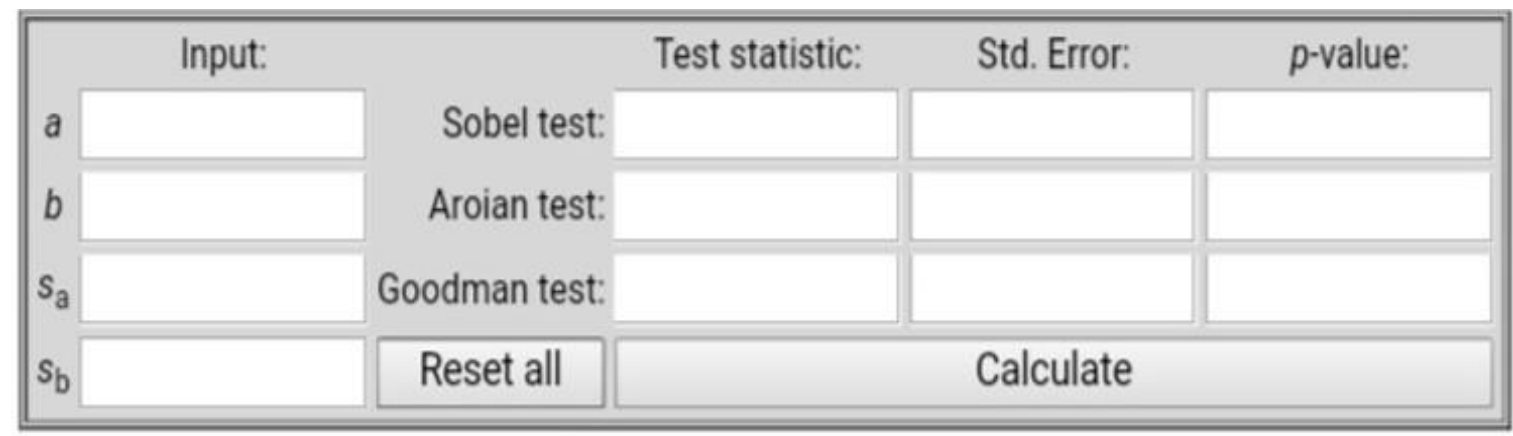

$a=$ raw (unstandardized) regression coefficient for the association between the IV and the mediator.

$s_{\mathrm{a}}=$ standard error of $a$.

$b=$ raw coefficient for the association between the mediator and the DV (when the IV is also a predictor of the DV).

$s_{\mathrm{b}}=$ standard error of $b$.

Figure 2. Sobel Test

To run this program, the unstandardized coefficient and the standard error of the independent variable talent management on the mediator emotional intelligence and the unstandardized coefficient and the standard error of independent variable talent management on the mediator emotional intelligence as predictors of the dependent variable organizational performance must be the inputs of this model. Table 3 summarizes the results of the unstandardized coefficients and standard errors. 
Table 3. Unstandardized coefficients and standard errors of the 4 models implemented

\begin{tabular}{|c|c|c|c|c|c|c|c|c|}
\hline \multirow[b]{2}{*}{ Variable } & \multicolumn{2}{|c|}{ Step 1 OP } & \multicolumn{2}{|c|}{ Step 2 EI } & \multicolumn{2}{|c|}{ Step 3 OP } & \multicolumn{2}{|c|}{ Step 4 OP } \\
\hline & $\begin{array}{l}\text { Unstandardized } \\
\text { Coefficient }\end{array}$ & $\begin{array}{l}\text { Standard } \\
\text { Error }\end{array}$ & $\begin{array}{l}\text { Unstandardized } \\
\text { Coefficient }\end{array}$ & $\begin{array}{l}\text { Standard } \\
\text { Error }\end{array}$ & $\begin{array}{c}\text { Unstandardized } \\
\text { Coefficient }\end{array}$ & $\begin{array}{l}\text { Standard } \\
\text { Error }\end{array}$ & $\begin{array}{l}\text { Unstandardized } \\
\text { Coefficient }\end{array}$ & $\begin{array}{c}\text { Standard } \\
\text { Error }\end{array}$ \\
\hline $\begin{array}{c}\text { Talent } \\
\text { Management }\end{array}$ & 0.467 & 0.059 & 0.482 & 0.060 & & & 0.438 & 0.071 \\
\hline $\begin{array}{c}\text { Emotional } \\
\text { Intelligence }\end{array}$ & & & & & 0.518 & 0.043 & & \\
\hline
\end{tabular}

The results of Sobel test show that emotional intelligence significantly mediated the effect of talent management on organizational performance (Z-value=3.657, $p \leq 0.01$ ). Therefore, the researcher conclusively accepts hypothesis four $\left(\mathrm{H}_{0} 4\right)$ that "emotional intelligence mediates the effect relationship between talent management and organizational performance". Figures 3 and 4 illustrate the direct and indirect effects of the study variables, while table 4 recapitulates the study's tested hypotheses.

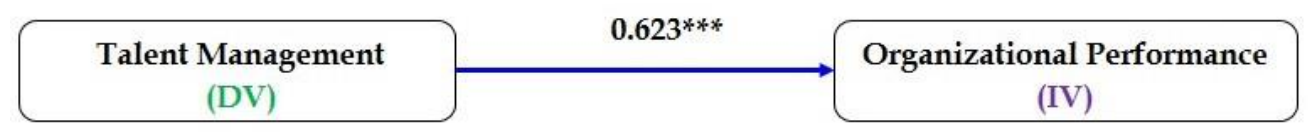

$* * * \mathrm{p} \leq 0.01$

Figure 3. Direct effect of Talent Management on Organizational Performance

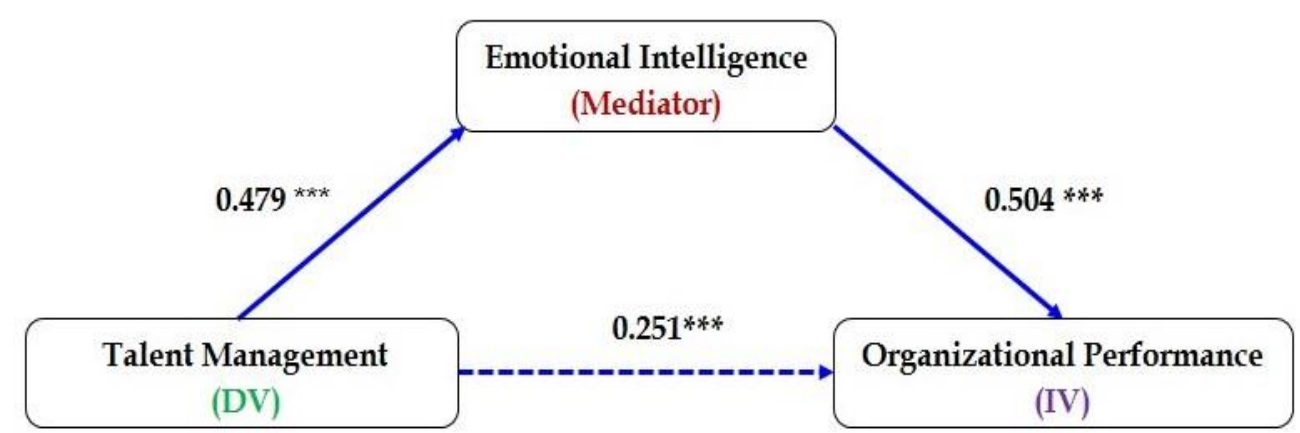

Figure 4. Effect of Talent Management on Organizational Performance through Emotional Intelligence $* * * \mathrm{p} \leq 0.01$

Table 4. Epitomizing results

\begin{tabular}{|c|c|c|c|}
\hline Hypothesis & Path & Effect & Result \\
\hline $\mathrm{H}_{0} 1$ & $\mathrm{TM} \longrightarrow \mathrm{OP}$ & $0.623 * * *$ & Accepted \\
\hline $\mathrm{H}_{0} 2$ & $\mathrm{TM} \longrightarrow \mathrm{EI}$ & $0.497 * * *$ & Accepted \\
\hline $\mathrm{H}_{0} 3$ & $\mathrm{EI} \longrightarrow \mathrm{OP}$ & $0.504^{* * *}$ & Accepted \\
\hline $\mathrm{H}_{0} 4$ & $\mathrm{TM} \longrightarrow \mathrm{EI} \stackrel{\mathrm{QP}}{\longrightarrow}$ & $0.251^{* * *}$ (indirect) & Accepted \\
\hline
\end{tabular}

\section{Discussion and conclusion}

This study explored the extent to which emotional intelligence can predict the effects of talent management on organizational performance in the Jordanian pharmaceutical industry. An integrated approach that studies the effects of emotional intelligence in the relationship between the effects of talent management on organizational performance was not found in previous studies because most of these studies, especially current ones, overlooked the important role of the psychological interactions among workers. However, this study highlights the role of emotionally talented workers over low emotionally talented workers as a predictor of high performance achievements. Thus, the study's findings supported all four hypotheses. 
Talent management plays an important role in business organizations and has important implications for organizational performance. Talented workers who possess high skills, competencies, knowledge, and capabilities can perform higher and have higher potential that is reflected in higher efficiency and effectiveness of both individuals and organizational performance. Therefore, pharmaceutical companies should always properly look to attract new talented employees, develop current and new onboard talented employees, and effectively retain them. Additionally, talent management is positively and significantly associated with organizational performance. Moreover, the study's results revealed that talent management has a positive and significant influence on emotional intelligence, while emotional intelligence has a positive and significant effect on organizational performance. Thus, in this respect, there is a consensus between scholars and academicians that the transition stage of development requires strong interpersonal leadership skills (leaders who interpersonally aware of social benevolence) as well as a high collaboration among individuals themselves is mandatory to ensure the sustainability of organizations. In other words, the ability to recognize and understand others' emotions can harmonize all talented workers to fuel their interactions in negatively emotionally charged situations such as customer relations. Thus, emotional intelligence is most important when forming teams and building work groups that require unifying all efforts and bringing individuals together to solve critical issues.

Talents' emotional intelligence is appropriate during stressful times to evaluate their own feelings and emotions and construct new strategies to cope with each other, either individually or in team. However, the study's findings revealed that emotional intelligence mediates the effect of talent management on organizational performance in the Jordanian pharmaceutical industry. Innately, emotional intelligence is inherited in every human being and is intangible. It affects every aspect of behaviour and how we responsively think and act. EI is made up of two core competencies; personal competence, which is focused more on individual personality than interactions with others, and on being aware of individual emotions and managing one's own behaviours and tendencies. Meanwhile, social competence focuses on understanding others' emotions and seeing the big picture around you. Emotional intelligence will definitely develop if an individual is continually learning new skills. Too many studies have proved that emotional intelligence is a good predictor of organizational performance. The pharmaceutical industry of Jordan is becoming competitive, global reaching and international, especially in the Middle East and North Africa (MENA). Thus, a corporate growth strategy was traced that required talented workers equipped with high potential, competencies, full understanding, high qualifications and knowledge combined with experience to sustainably achieve the strategic target (Martin, 2014; Al-Jallad, 2017).

\subsection{Practical implications}

The current research study is focused on the pharmaceutical industry of Jordan. This study employed the Goleman scale of emotional intelligence as a mediator of this research. Future studies can use the same variables of this study in other sectors and examine the effects of emotional intelligence on leadership powers to drive expansion strategies. In the current study, emotional intelligence and talent management are analysed with organizational performance. Future studies should consider other dependent variables, such as strategic agility, vigilance and business intelligence. Eventually, some of the contextual variables, such as employee engagement, can be added to the theoretical framework, and a mediator can also be employed.

\section{References}

Abdul-Kareem, Aleem (2016). Best Practices for Talent Management: Critical Drivers for Organizational Success and Survival. European Journal of Business and Management, 8(25), 98-105.

Abraham, Rebecca (2004). Emotional Competence as Antecedent to Performance: A Contingency Framework. Genetic, Social, and General Psychology Monographs, 130(2), 117-145. Doi: https://doi.org/10.3200/MONO.130.2.117-145.

Agnello, Paul, Ryan, Rachel, Yusko, Kenneth P. (2015). Implications of modern intelligence research for assessing intelligence in the workplace. Human Resource Management Review, 25(1), 47-55.

Doi: https://doi.org/10.1016/j.hrmr.2014.09.007. 
Al-Azzam, Zeyad F. (2015). The Effects of Perceived Transformational Leadership Style and Emotional Intelligence on Enhancing the Effectiveness of Decision Making in Public Health Sector. International Journal of Advanced Research, 3(12), $1665-1682$.

Al-Azzam, Zeyad Faisal, Irtaimeh, Hani Jazza'a \& Khaddam, Amineh Abdul Halim (2017). Examining the Mediating Effect of Strategic Agility in the Relationship between Intellectual Capital and Organizational Excellence in Jordan Service Sector. Journal of Business, 6(1), 7-15.

Ali, Shaemi, Mohsen, Allameh Seyed \& Mahboobeh, Askari (2013). Talent Management Strategies and its Relation with Employees' Emotional Intelligence. Journal of Management Studies in Development E Evaluation, 23(70), 4775.

Al-Jallad, Tariq A. (2017). Strategies for Business Capacity Expansion in Jordanian Pharmaceutical Companies. Ph.D. Dissertation: Walden University. UK.

Al Jarrah, Saleh Ali \& Abu-Doleh, Jamal Daoud (2015). The Impact of Applying Talent Management Strategies in Enhancing the Organizational Affiliation among Faculty Members in Jordanian Public Universities. Jordan Journal of Business Administration, 11(2), 283-315.

Antonakis, J., Ashkanasy, N. M. \& Dasborough, M. T. (2009). Does leadership need emotional intelligence? The Leadership Quarterly, 20(2), 247-261.

Anwar, A., Nisar, Q. A., Khan, N. Z. A. \& Sana, A. (2014). Talent Management: Strategic Priority of Organizations. International Journal of Innovation and Applied Studies, 9(3), 1148-1154.

Arif, A. A. \& Uddin, M. R (2016). Talent Management and Organizational Performance: An Empirical Study in Retail Sector in Sylhet City, Bangladesh. Journal of Business and Management (IOSR-JBM), 18(10/IV), 11-18. Doi: http://10.9790/487X-1810041118.

Arribas-Galarraga, S., Saies, E., Cecchini, J. A., Arruza, J. \& Cos, I. LD. (2017). The relationship between emotional intelligence, self-determined motivation and performance in canoeists. Journal of Human Sport and Exercise, 12(3), 630-639. Doi: https://doi.org/10.14198/jhse.2017.123.07.

Asrar-ul-Haq, M., Anwar, S. \& Hassan, M. (2017). Impact of emotional intelligence on teacher's performance in higher education institutions of Pakistan. Future Business Journal, 3, 87-97. http://dx.doi.org/10.1016/j.fbj.2017.05.003.

Bano, S., Khan, M. A., Rehman, Q. H. U. \& Humayoun, A. A. (2010). Schematizing talent management: a core business issue. Far East Journal of Psychology and Business, 2(1), 4-16.

Beechler, Schon \& Woodward, Ian C. (2009). The global "war for talent". Journal of International Management, 15, 273285.

Brouwers, Symen A. \& Vijver, Fons J.R. van de (2015). Contextualizing intelligence in assessment: The next step. Human Resource Management Review, 25(1), 38-46. Doi: https:/ / doi.org/10.1016/j.hrmr.2014.09.006.

Calik, B. \& Birgili, B. (2013). Multiple Intelligence Theory for Gifted Education: Criticisms and Implications. Journal for the Education of the Young Scientist and Giftedness, 1(2), 1-12.

Cappelli, Peter \& Keller, JR. (2014). Talent Management: Conceptual Approaches and Practical Challenges. Annual Review of Organizational Psychology and Organizational Behaviour, 1, 305-331. Doi: https://doi.org/10.1146/annurev-orgpsych-031413-091314.

Chaudhry, Amjad Ali \& Usman, Abid (2011). An Investigation of the Relationship between Employees' Emotional Intelligence and Performance. African Journal of Business Management, 5(9), 3556-3562. Available at SSRN: https://ssrn.com/abstract=2171775.

Chopra, P. K. \& Kanji, G. K. (2010). Emotional intelligence: a catalyst for inspirational leadership and management excellence. Total Quality Management, 21(10), 971-1004.

Clake, R. \& Winkler, V. (2006). Change Agenda: Reflections on Talent Management. Chartered Institute for Personnel Development (CIPD), London.

Codier E., Kamikawa C., Kooker B. M., Shoultz J. (2009). Emotional intelligence, performance, and retention in clinical staff nurses. Nurs Adm Q., 33(4), 310-316. doi: http://10.1097/NAQ.0b013e3181b9dd5d.

Collings, D. G., Scullion, H. \& Vaiman, V. (2011). European perspectives on talent management. European Journal of International Management, 5(5), 453-462.

Cooke, F. L., Saini, D. S. \& Wang, J. (2014). Talent management in China and India: A comparison of management perceptions and human resource practices. Journal of World Business, 49, 225-235.

Cooper, R. K. (1997). Applying emotional intelligence in the workplace. Training E Development, 51(12), 31-38. Google Scholar.

Daneshfard, K., Rajaei, Z., Bilondi, Z.M. \& Banihashemi, S.A. (2016). The Effect of Organizational Intelligence on Talent Management, Using Structural Equations. International Journal of Humanities and Cultural Studies, 3(2), 464-467.

Davies, B. \& Davies, B. J. (2010). Talent Management in academies. International Journal of Education Management, 24(5), 418-426. Doi: https://doi.org/10.1108/09513541011055983. 
Deshmukh, G. K. (2012). Talent Management: A Conceptual Framework with Practical Approach. Asian J. Management, 3(1), 48-50.

Elegbe, J. A. (2010). Talent Management in the Developing World, Farnham, Survey. Ashgate Publishing Group, Great Britain.

Fagan, Joseph \& Ployhart, Robert E. (2015). The information processing foundations of human capital resources: Leveraging insights from information processing approaches to intelligence. Human Resource Management Review, 25(1), 4-11. Doi: https://doi.org/10.1016/j.hrmr.2014.09.003.

Gallardo-Gallardo, E., Dries, N. \& Gonzalez-Cruz, T. (2012). What is the meaning of 'talent' in the world of work?. Human Resource Management Review, 23, 290-300.

Gallardo-Gallardo, Eva, Nijs, Sanne, Dries, Nicky \& Gallo, Pedro (2015). Towards an understanding of talent management as a phenomenon-driven field using bibliometric and content analysis. Human Resource Management Review, 25(3), 264-279. Doi: https://doi.org/10.1016/j.hrmr.2015.04.003.

Gardner, H. (1983). Frames of mind: The theory of multiple intelligences. New York: Basic Books.

Gardner, H., \& Hatch, T. (1989). Multiple intelligences go to school: Educational implications of the theory of multiple intelligences. Educational Researcher, 18(8), 4-9.

Golparvar, M. \& Khaksar, F. (2010). The relationship between emotional intelligence and job performances in a set of industrial factories in Isfahan. Clinical Psychology \& Personality, 1(40), 19-34.

Gutiérrez-Cobo, M. J., Cabello, R. \& Fernández-Berrocal, P. (2017). Performance-based ability emotional intelligence benefits working memory capacity during performance on hot tasks. Scientific Reports 7, Article number: 11700. Doi: http://doi:10.1038/s41598-017-12000-7.

Gutiérrez-Cobo M. J., Cabello R. \& Fernández-Berrocal P. (2017). The Three Models of Emotional Intelligence and Performance in a Hot and Cool go/no-go Task in Undergraduate Students. Front Behav Neurosci., 22, 11-33. Doi: http:/ /10.3389/fnbeh.2017.00033. eCollection 2017.

Hakkak, M., Nazarpoori, A., Mousavi, S. N., \& Ghodsi, M. (2015). Investigating the effects of emotional intelligence on social-mental factors of human resource productivity. Journal of Work and Organizational Psychology, 31(3), 129134. Doi: https://doi.org/10.1016/j.rpto.2015.06.005.

Haines, sue (2013). Applying talent management to nursing. Nursing Times, 109(47), 12-15. www.nursingtimes.net.

Hair, G., Black, B., Babin, B., Anderson, R. and Tatham, R. (2010). Multivariate Data Analysis. 7th Edition, Pearson, Upper Saddle River, New Jersey.

Hanif, Muhammad Imran \& Yunfei, Shao (2013). The role of talent management and HR generic strategies for talent retention. African Journal of Business Management, 7(29), 2827-2835. Doi: http://10.5897/ AJBM2012.1369.

Healy, S. H., El-Atroush, H., Abol-Enein, H. \& El-Sayed, N. M. (2013). Emotional intelligence and its relation to nursing performance among nurses at Mansoura University Hospital and Urology and Nephrology Center. The Medical Journal of Cairo University, 81(1), 689-697.

Higgs, Malcolm, (2004). A study of the relationship between emotional intelligence and performance in UK call centres. Journal of Managerial Psychology, 19(4), 442-454. Doi: https://doi.org/10.1108/02683940410537972.

Hills, A. (2009). Succession planning or smart talent management. Industrial and Commercial Training, 41(1), 3-8.

Horváthová, Petra (2011). The Application of Talent Management at Human Resource Management in Organization. 3rd International Conference on Information and Financial Engineering, IPEDR 12, 50-54.

Ibidunni, S., Osibanjo, O., Adeniji, A., Salau, O. P., \& Falola, H. (2016). Talent Retention and Organizational Performance: A Competitive Positioning in Nigerian Banking Sector. Periodica Polytechnica Social and Management Sciences, 24(1), 1-13, Doi: http:/ /10.3311/PPso.7958.

Iles, P. (2008). Talent balancing: Staffing your company for long-term success. Human Resource Development International, 11(2), 215-218.

Irtaimeh, Hani J., Al-Azzam, Zeyad F. \& Khaddam, Amineh A. (2016). Exploring the Impact of Talent Management Strategies and Service Quality on Beneficiaries Satisfaction in Jordan Healthcare Sector: Provider point of View. International Journal of Management (IJM), 7(7), 23-38.

Ingram, Tomasz (2016). Relationships between Talent Management and Organizational Performance: The Role of Climate for Creativity. Entrepreneurial Business and Economics Review, 4(3), 195-205, DOI: http:/ / dx.doi.org/10.15678/EBER.2016.040315.

Jorfi, Hassan, Jorfi, Saeid \& Moghadam, Sirous Korahi (2010). Impact of Emotional Intelligence on Performance of Employees. Postmodern Openings, 1(4), 63-74.

Jyoti, Jeevan \& Rani, Roomi (2014). Exploring talent management practices: antecedents and consequences. Int. J. Management Concepts and Philosophy, 8(4), 220-248.

Judd, C. M. \& Kenny, D. A. (1981). Process Analysis: Estimating mediation in treatment evaluations. Evaluation Review, 5(5), 602-619.

Kaur, R. (2013). Empirical study of talent management program and its impact on the employee's retainment and performance in Indian supermarket big bazaar. Human Resource Management Research, 3(3), 61-70.

www.jbrmr.com A Journal of the Academy of Business and Retail Management (ABRM) 
Keating, R. J., Harper, S. C. \& Glew, D. J. (2013). Emotional intelligence dilutes the toxins. Industrial Engineer, $45(6), 30$.

Kesyer, John (2013). Emotional Intelligence Is Key to Our Success. ATD, https://www.td.org/insights/emotionalintelligence-is-key-to-our-success. Retrieved date: 6/12/2017.

Latukha, Marina (2016). Talent management in Russian companies: domestic challenges and international experience. The International Journal of Human Resource Management, 26(8), 1051-1075. Doi:

https://doi.org/10.1080/09585192.2014.922598.

Latukha, Marina \& Selivanovskikh, Louisa (2016). Talent Management Practices in IT Companies from Emerging Markets: A Comparative Analysis of Russia, India, and China. Journal of East-West Business, 22(3), 168-197. Doi: https://doi.org/10.1080/10669868.2016.1179702.

Lewis, R. E. \& Heckman, R. J. (2006). Talent management: a critical review. Human Resource Management Review, 16(2), 139-154.

Lyons, Joseph B. \& Schneider, Tamera R. (2005). The influence of emotional intelligence on performance. Personality and Individual Differences, 39(4), 639-703. Doi: https://doi.org/10.1016/j.paid.2005.02.018.

MacKinnon, D. P., Warsi, G., \& Dwyer, J. H. (1995). A simulation study of mediated effect measures. Multivariate Behavioural Research, 30(1), 41-62. Doi: http://10.1207/s15327906mbr3001_3.

MacKinnon, D. P., \& Dwyer, J. H. (1993). Estimating mediated effects in prevention studies. Evaluation Review, 17(2), 144-158. Doi: https://doi.org/10.1177/0193841X9301700202.

Martin, R. (2014). The big lie of strategic planning. Harvard Business Review, 92(1/2), 3- 8. Retrieved from https://hbr.org.

Maya, M. \& Thamilselvan, R. (2013). Impact of Talent Management on Employee Performance and Organizational Efficiency in ITSP'S- with Reference to Chennai City. IJER, 10(2), 453-461.

Mayer, John D., Roberts, Richard D. \& Barsade Sigal G. (2008). Human abilities: emotional intelligence. Annual Review of Psychology, 59, 507-536, https://doi.org/10.1146/annurev.psych.59.103006.093646.

Mayor, John D., Salovey, Peter \& Caruso, David R. (2004). Emotional Intelligence: Theory, Findings, and Implications. Psychology Inquiry, 15(3), 197-215.

Mensah, James Kwame (2015). A “coalesced framework" of talent management and employee performance: For further research and practice. International Journal of Productivity and Performance Management, 64(4), 544-566, https://doi.org/10.1108/IJPPM-07-2014-0100.

Michaels, Ed, Handfield-Jones, Helen, \& Axelrod, Beth. (2001). The War For Talent. Harvard Business School Press, Boston, MA.

Mohamad, Mafuzah \& Jais, Juraifa (2016). Emotional Intelligence and Job Performance: A Study Among Malaysian Teachers. 7th International Economics \& Business Management Conference, 5th \& 6th October 2015. Procedia Economics and Finance, 35, $674-682$.

Nankervis, A. R. (2013). Building for the future? Government and industry responses to the challenges of talent management in China following the GFC. Asia Pacific Business Review, 19(2), 186-199.

Njoroge, Caroline Ngonyo \& Yazdanifard, Rashad (2014). The Impact of Social and Emotional Intelligence on Employee Motivation in a Multigenerational Workplace. Global Journal of Management and Business Research: A, 14(3/1), 31-36.

O'Boyle, Ernest H. Jr., Humphrey, Ronald H., Pollack, Jeffrey M., Hawver, Thomas H. \& Story, Paul A. (2011). The relation between emotional intelligence and job performance: A meta-analysis. Journal of Organizational Behavior, 32(5), 788-818. Doi: http://10.1002/job.714.

Offermann, Lynn R., Bailey, James R., Vasilopoulos, Nicholas L., Seal, Craig \& Sass, Mary (2004). The Relative Contribution of Emotional Competence and Cognitive Ability to Individual and Team Performance. Human Performance, 17(2), 219-243. Doi: https://doi.org/10.1207/s15327043hup1702_5.

Palmer, Benjamin R. \& Gignac, Gilles (2012). The impact of emotionally intelligent leadership on talent retention, discretionary effort and employment brand. Industrial and Commercial Training, 44(1), 9-18, Doi: https://doi.org/10.1108/00197851211193372.

Payambarpour, S. A. \& Hooi, L. W. (2015). The impact of talent management and employee engagement on organizational performance. Int. J. Management Practice, 8(4), 311-336.

Pekaar, Keri A., Linden, Dimitri van Der, Bakker, Arnold B. \& Born, Marise Ph. (2017). Emotional intelligence and job performance: The role of enactment and focus on others' emotions. Human Performance, 30(2-3), 135-153. Doi: https://doi.org/10.1080/08959285.2017.1332630.

Piansoongnern, O., Anurit, P. \& Kuiyawattananonta, S. (2011). Talent management in Thai cements companies: a study of strategies and factors influencing employee engagement. African Journal of Business Management, 5(5), 1578-1583.

Rahim, Saddam Hussain \& Malik, Muhammad Imran (2010). Emotional Intelligence \& Organizational Performance: (A Case Study of Banking Sector in Pakistan). International Journal of Business and Management, 5(10), $191-197$. 
Ross, Suzanne (2013). How definitions of talent suppress talent management. Industrial and Commercial Training, 45(3), 166-170, https://doi.org/10.1108/00197851311320586.

Sart, Gamze (2014). The impact of Strategic Talent Management Assessments on Improving Innovation-Oriented Career Decisions. Anthropologist, 18(3), 657-665.

Scherbaum, Charles A. \& Goldstein, Harold W. (2015). Intelligence and the modern world of work. Human Resource Management Review, 25(1), 1-4. Doi: https:// doi.org/10.1016/j.hrmr.2014.09.002.

Schiemann, W.A. (2014). From talent management to talent optimization. Journal of World Business, 49, $281-288$.

Schneider, W. Joel \& Newman, Daniel A. (2015). Intelligence is multidimensional: Theoretical review and implications of specific cognitive abilities. Human Resource Management Review, 25(1), 12-27. Doi:

https://doi.org/10.1016/j.hrmr.2014.09.004.

Shayanipour, Z., Imani, M. N. \& Karimzadeh, S. (2017). An Appropriate Model for Talent Management Based on Emotional, Organizational and Cultural Intelligence. Iranian Journal of Educational Sociology, 1(5), 66-77.

Silzer, R. \& Church, A. H. (2010). Identifying and assessing high-potential talent: current organizational practices. In Silzer, R. \& Dowell, B. E. (Eds.): Strategy-Driven Talent Management: A Leadership Imperative, Jossey-Bass, San Francisco, 213-279.

Sobel, M. E. (1982). Asymptotic confidence intervals for indirect effects in structural equation models. In S. Leinhardt (Ed.), Sociological Methodology 1982 (pp. 290-312). Washington DC: American Sociological Association.

Srivastava, Kalpana (2013). Emotional intelligence and organizational effectiveness. Industrial Psychiatry Journal, 22(2), 97-99, doi: http://10.4103/0972-6748.132912.

Stahl, Günter K., Björkman, Ingmar, Farndale, Elaine, Morris, Shad S., Paauwe, Jaap, Stiles, Philip, Trevor, Jonathan \& Wright, Patrick (2012). Six Principles of Effective Global Talent Management. MIT Sloan Management Review, 53(2), 25-32.

Tajuddin, Dewi, Hassan, Roshidi, Nasir, Syed Abdul Jamal M. \& Ali, Rosalan (2016). Investment in Human Capital for sustainable growth and Profits: The Need of Talent Management Framework for Malaysian Banks. GEInternational Journal of Management Research, 4(2), 1-18.

Talarico, J. F., Metro, D. G., Patel, R. M., Carney, P. \& Wetmore, A. L. (2008). Emotional intelligence and its correlation to performance as a resident: a preliminary study. Journal of Clinical Anaesthesia, 20(2), 84-89.

Tansley, C. (2011). What do we mean by the term 'talent' in talent management? Industrial and Commercial Training, 43(5), 236-247.

Thunnissen, M., Boselie, P. \& Fruytie, B. (2013). A review of talent management: Infancy or adolescence. The International Journal of Human Resource Management, 24(9), 1744-1761.

Vahidi, Maryam, Areshtanab, Hossein Namdar \& Bostanabad, Mohammad Arshadi (2016). The Relationship between Emotional Intelligence and Perception of Job Performance among Nurses in North West of Iran. Scientifica, 2016. Doi: http:/ /dx.doi.org/10.1155/2016/9547038.

Vaiman, V., Scullion H., \& Collings, D. (2012). Talent management decision making. Management Decisions, 50(5), 925941. Doi: https://doi.org/10.1108/00251741211227663.

Vaiman, Vlad, Haslberger, Arno \& Vance, Charles M. (2015). Recognizing the important role of self-initiated expatriates in effective global talent management. Human Resource Management Review, 25(3), 280-286. Doi: https://doi.org/10.1016/j.hrmr.2015.04.004.

Valverde, M., Scullion, H. \& Ryan, G. (2013). Talent management in Spanish medium-sized organizations. The International Journal of Human Resource Management, 24(9), 1832-1852.

Vaiman, V. \& Collings, D. G. (2013). Talent management: advancing the field. The International Journal of Human Resource Management, 24(9), 1737-1743.

Wong C. S. \& Law K. S. (2004). The effects of leader and follower, Emotional intelligence performance and attitude: An explanatory study. Leadership Quarterly, 13(3), 243-274. 